\title{
Public Inclination Towards Waste Segregation Programme (A Case Study on the Effectiveness Of \#Asingkan Campaign in Klang Valley)
}

\author{
Intan Abida Abu Bakar ${ }^{1}$, Srikumar K. Ramayan ${ }^{2}$ and Vijaya Sooria Sangaran ${ }^{3}$ \\ Department of Communication, School of Arts, Sunway University, MALAYSIA

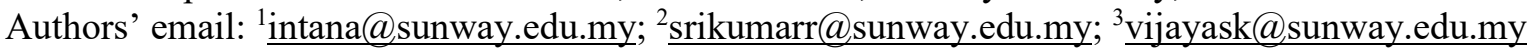

Published: 28 September 2020

\begin{abstract}
This paper investigates the effectiveness of the \#Asingkan Waste Segregation Campaign in Klang Valley area. In September 2015, the Urban Well-being, Housing and Local Government Ministry began enforcing Act 672 of the Solid Waste and Public Cleansing Management Act 2007. The Act makes it compulsory for residents to separate their solid wastes according to categories of paper, plastics and others or face fines between RM50 and RM500. This Segregation programme affects those living in Putrajaya and Kuala Lumpur, Johor, Malacca, Negeri Sembilan, Kedah, Perlis and Pahang. The main objective of this research is to investigate the awareness level of public towards waste segregation programme and analyse the effectiveness of \#Asingkan campaign. Data from questionnaires and focus group discussions indicate that the waste segregation programme and the \#Asingkan campaign are not running effectively. The Malaysian Government should find the right approach to educate and change the public's attitude in order to make sure this programme successful.

Keywords: Waste Segregation, Effectiveness, \#Asingkan Campaign, Klang Valley
\end{abstract}

eISSN: 2550-214X (C) 2020. The Authors. Published for Idealogy Journal by UiTM Press. This is an Open Access article distributed under the terms of the Creative Commons Attribution-NonCommercial-NoDerivatives License (http://creativecommons.org/licenses/by-nc-nd/4.0/), which permits non-commercial re-use, distribution, and reproduction in any medium, provided the original work is properly cited, and is not altered, transformed, or built upon in any way.

\section{INTRODUCTION}

Every year an estimated 1.3 billion tonnes of solid waste were collected worldwide. According to Hoornweg and Bhada-Tata (2012), the quantity of solid waste is expected to reach 2.2 billion tonnes per year by the year 2025 with almost the increasing were from developing countries. Malaysia is a developing country with the urbanization and population growth has resulted the increasing amount of solid waste. It has become a crucial issue to be solved.

With a population of over 32 million, Malaysia generates about 38,000 metric tonnes of waste on a daily basis. Referring to Solid Waste Management Lab 2015 Report, it is estimated that 49,670 tonnes per day of waste is expected to be generated by Malaysians in the year 2020. In total, Malaysia produces 138 million tonnes of waste a year and it costs RM1 billion to manage this. According to Housing and Local Government Minister Zuraida Kamaruddin, out of the huge amount of solid waste, the waste separation and recycle rate is only at $24 \%$, while the remaining $76 \%$ goes to the landfill (The Star Online, 2018).

In major cities, such as Kuala Lumpur, it is estimated that the generation of waste is about $1.5 \mathrm{~kg} / \mathrm{person} /$ day (Budhiarta et al., 2011). Authorities in most major cities in Malaysia are seeking for an alternative waste management approach as the landfill approach currently adopted becomes unsustainable due to rapid development and lack of new landfill spaces.

Globalrecycling.eu reported, food waste is a major component of generated waste (45 percent) and contains high organic compounds. Due to unseparated waste, more than 30 percent potentially recyclable materials such as paper, plastic, aluminium and glass are still directly disposed of in landfills. 
The Malaysian government plans to reduce the waste disposed of in landfills. By the year 2020, the reduction shall amount to 40 percent through 22 percent recycling and 80 percent intermediate treatment such as waste-to-energy, composting and material recovery.

The lack of an effective and efficient waste management system has had a negative impact on the environment. The country's build-up of solid waste is resulting in tremendous land and air pollution of the environment, health problems for communities and bottlenecks to economic growth (cleanmalaysia.com, 2015). The current waste management methods by Malaysia government is incineration, which is not environmentally friendly. The incineration can cause air pollution, which is the main factor of acid rain as toxic substance was generated through plastic burning and the ash from incinerators contain heavy metal and other toxins (GreenChoices, 2016).

The majority of landfills in Malaysia is open-air pits. This open-air landfill method is cheap, but rough on the environment. Open-air landfills can cause surface and groundwater contamination through leaching, soil contamination through direct contact, air pollution through garbage burning, disease spread through birds, insects and rodents, uncontrolled release of greenhouse gases and very unpleasant odour (GreenChoices, 2016). Based on Clean Malaysia (2015), today 85 percent of the landfills in Malaysia are expected to shut down in the next few years as it has reached the full capacity, but this issue can be resolved due to the fact that over 50 percent of the waste produced by Malaysians can be recycled.

On 1 September 2015, the Malaysian government has made compulsory to separate solid waste in pursuant to regulations under the Solid Waste and Public Cleaning Management Act 2007 (Act 672) enforced in the following states and Federal Territories: Kuala Lumpur, Putrajaya, Johor, Melaka, Negeri Sembilan, Pahang, Kedah, and Perlis (Ministry of Urban Wellbeing, Housing and Local Government, 2015). The waste segregation rule was formulated in 2014 under the Solid Waste Management and Public Cleansing Management Act 2007, and enforced in September 2015 (Free Malaysia Today online, 2019).

A Malaysian who live in the enforcement areas are required to separate their trash into two main categories; which are residual waste and recyclable waste. Based on the collection schedule, the residual waste will be collected twice a week while the recyclable waste and bulky waste will be collected once a week (Ministry of Urban Wellbeing, Housing and Local Government, 2015). A fine will only be charged to those who failed to separate their waste from 1 June 2016 onwards even though the Waste Separation Campaign \#Asingkan was effective from 1 September 2015 (The star online, 2015).

The Minister of Urban Wellbeing, Housing and Local Government; Datuk Abdul Rahman Dahlan mentioned that the ministry had execute few awareness efforts, including distributed pamphlets and flyers, print and electronic advertisements, and promotions on social media, such as Twitter which hashtags of the campaign \#Asingkan and \#Keepitseparated hit 16.7 million exposures (The star online, 2015). As stated by Reubsaet (2009), we can increase knowledge and shape the attitude of a target group through the campaign. Deputy Minister of Housing and Local Government Senator Datuk Raja Kamarul Bahrin Shah Raja Ahmad Baharuddin Shah said the government would continue carrying out advocacy campaigns to create public awareness of the importance of preserving the environment (Malay Mail online, 2019).

\subsection{Statement of Problem}

It is a serious issue in Malaysia now where the efforts made by the Government are not completely appreciated and understood by Malaysians, therefore the result of Waste Separation Campaign \#Asingkan is unpredictable unknown. A big reason for the waste problem in Malaysia is that its people are facing a profound lack of public awareness and environmental education. The effectiveness of \#Asingkan is yet to be determined as the Government receives such weak response from Malaysians, whether they execute it in the most appropriate way to direct the idea intended. 
Malaysian Government had to allocate a massive amount of the budget annually to organise and run Green Campaign such as \#Asingkan to educate Malaysian about Environmental health, including ways to preserve and conserve the environment for a greener future; but the outcomes were not as good as it was supposed to be. The low awareness of the rise of environmental issue around Malaysians can lead to a disaster as the environment is slowly being destroyed and Malaysian should pay more attention and efforts in contributing to a sustainable future. Public awareness of solid waste segregation has yet to reach a satisfactory level, although the government has made this compulsory since September 2015.

\subsection{Objective of the Study}

The objectives of this research are:

1. To analyse the effectiveness of the \#Asingkan Campaign in Klang Valley.

2. To investigate the awareness level of public towards waste segregation programme.

\section{WASTE MANAGEMENT IN MALAYSIA}

As landfilling is currently the ultimate waste disposal method that can deal with many types of materials, most of the garbage ends on landfill sites. Most landfills in this country are small scale operations with varying designs and a lot of these sites are poorly maintained. Malaysia is one of the developing countries, therefore the waste generation in Malaysia has rapidly increased. One of the major issues for most of the developing countries are the environmental health issues and research shown that the waste management in most of the developing country is yet to be well developed. (Badgie, Samah, Manalf, \& Muda, 2012).

Solid waste management were responsible by the local authorities and the state government under the Local Government Act of 1976. According to the Solid Waste Management and Public Cleansing Corporation (SWCorp Malaysia), there are only 14 sanitary landfills all over the country; 161 landfills are still in operation, while 141 are closed. As reported by SWCorp Malaysia, there are several incinerators in the country with a capacity of 75 tons/day in total. A facility for construction and demolition waste is able to treat 500 tons per day. The organic waste is treated in collaboration with Kitakyushu City Hall, Japan (500 tons/year), in Malaysian food waste facilities (anaerobic digester: 1,500 kilograms/day) and composting plants (150 kilograms/day).

The Malaysia government needs to improve the waste management system through the application of the waste management campaign such as 3Rs: Reduce, Reuse and Recycle. The majority of Malaysian is not ready to include the waste segregation as part of their lifestyle. Hence, a combined effort must be done to reduce the amount of solid waste. It has required a full cooperation from the general public with the government or non-governmental bodies (Badgie et al., 2012). After all, the government still has to manage the waste so there are few options waste management shown below.

\subsection{Waste Management Options}

\subsection{Source Reduction and Reuse}

The most basic way of waste management is source reduction. Source reduction can be accomplished through the advanced technology today, which the manufacture produces reusable products and packaging. Besides, public education on waste management, government policy initiatives, proper waste separation will ease the recovery of recyclable material at the dump site. 


\subsection{Recycling and Composting}

Recycling is reviving a used material into a new useful products and it is a better alternative compare to incineration and landfill process. Recycling has a lot of benefit which is the reduction of litter, the reduction of the need for disposal capacity, reduction of emissions from landfills and incinerators, conserves and lessens impact on raw materials during extraction.

\subsection{Landfill}

Landfill is the waste disposal method for all kinds of waste due to the fact that it is just a physical facility used for solid and residual waste disposal. The waste during the landfill process undergo a complex process which produces a vast amount of pollution, such as methane gas to the atmosphere and leachates to the soil.

\subsection{Incineration}

Incineration is a process of waste management where the waste burnt with controlled high temperature burning which includes sterilization and stabilization. Incineration is the only option of waste management when the waste composition is highly combustible because landfilling is not suitable for such waste.

Solid waste management should be embraced by each and every household. According to the Ministry of Urban Well-being, Housing and Local Government, there are four categories of wastes that need to be separated accordingly which are:

1. Paper - discarded receipts, cardboard, paper, newspapers, magazines, drink cartons and anything made of paper that's dry/uncontaminated.

2. Plastic - bottles, plastic bags, and anything else made of plastic (this can include plastic toys and plastic and polystyrene food containers - rinsed first).

3. Miscellaneous - pack and separate according to these groups:

a. Glass/ceramic wares (bottles, pots, etc.)

b. Aluminium/metal (such as cans, steel utensils, etc.)

c. Electronics (batteries, calculators, phones, wires, cables, light bulbs and small electrical items).

d. Fabric/shoes/rubber/leather (T-shirts, handbags, sneakers, rubber gloves, etc.)

e. Hazardous waste (aerosol cans, insect poison/repellent, paint cans).

f. Bulk items (furniture, bed frame, large electrical items).

g. Garden waste (leaves, flowers, etc.)

4. Non-recyclable - residual waste such as food items and soiled/wet materials like using diapers and tissues. Only these will be sent to landfills.

Solid wastes like e-waste and hazardous wastes need to be prevented from being dumped into the landfills because when they are released to the environment, they may cause biological and physiochemical problems to the environment and may affect or alter the productivity of the soil in that particular area.

The toxic materials released from them also will eventually seep into the soil and pollute the groundwater. Apart from that, during the disposal stage, the mixing up of hazardous wastes, plastics, papers and other scraps that need to be burned which will produce dioxins and gases. These toxic gases have a potential of causing various diseases including cancer.

\subsection{Public Participation on Green Campaigns in Malaysia}

There are few environmental related campaigns were done by the Malaysian government to promote environment friendly behaviour among Malaysian. Environmental degradation is occurring on a global 
scale and it is known as human beings' responsibility. Therefore, the green campaigns aim to raise an awareness and to educate the public regarding the environmental issues.

According to Housseinpour, Mohamed, Rezai, Shamsudin, \& Ismail (2015), the campaign can act as a tool to educate and change the target audience's perception and behaviour, and optimizing environmental campaign is not an easy task as the effects of such campaign may be significant to a small group but not the society as a whole. Their research objective is to investigate how go green campaign's effects on Malaysian's intention towards green behaviour. There is a positive attitude toward go green campaign among the respondents. They claimed that go green campaign was successful, influential in building participant intention to perform green behaviour.

\section{RESEARCH METHODOLOGY}

This study is investigating the awareness level of public towards waste segregation programme. For this research study, a quantitative approach is opted to further investigate the effectiveness of Waste Segregation \#Asingkan Campaign in Klang Valley area. The selected places are Sunway Pyramid, One Utama, Mid Valley and Pavillion. Due to the crowds and a positive number of the visitors, these shopping malls has been chosen to be the location and a total of 100 respondents were chosen randomly to answer the survey.

Secondary data content analysis is from the journals and newspaper reports of Waste Segregation Programme campaign and the researcher has gathered 25 news items from the year 2010 to the year 2018. The newspaper selected for the studies were The New Straits Times, The Sun, Malay Mail, Malaysiakini, Free Malaysia Today, Time Out and The Star. These newspapers are the major newspapers in Malaysia.

\section{DATA ANALYSIS}

The researcher has accomplished the data collection process by collecting 100 feedbacks from the random respondents in Klang Valley area. 25 survey questionnaires were randomly distributed to the target audience for each location in order to cover as wide as possible. Then, the results that received through the survey questionnaire are translated into the table and bar charts as shown below by using the SPSS Analysis Software.

Table 1: Have you heard of \#Asingkan Campaign?

\begin{tabular}{lccrcc}
\hline & & Frequency & Percent & Valid Percent & Cumulative Percent \\
\hline Valid & Yes & 15 & 15.0 & 15.0 & 15.0 \\
& No & 85 & 85.0 & 85.0 & 100.0 \\
& Total & 100 & 100.0 & 100.0 & \\
\hline
\end{tabular}




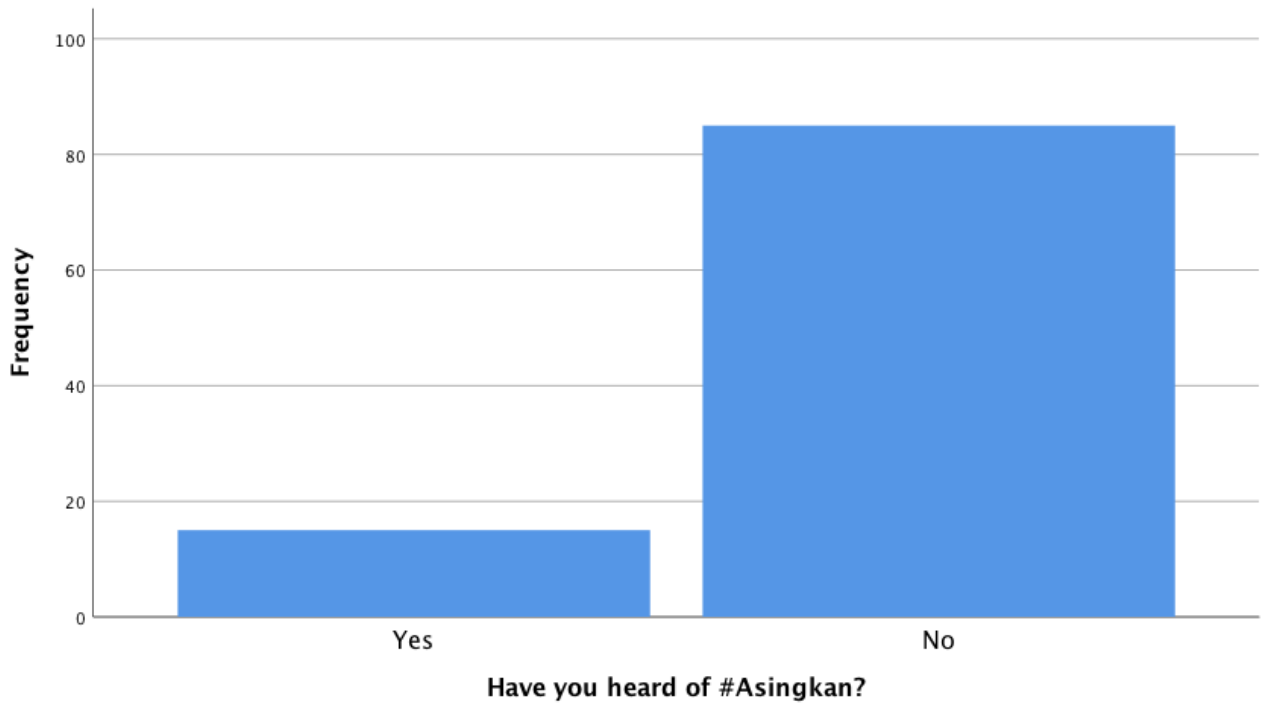

Figure 1: Shows the frequency of \#Asingkan's Campaign exposure

The chart shows only $15 \%$ of the respondents are aware of the Waste Separation \#Asingkan Campaign, while $85 \%$ of the respondents has not expose to the campaign at all.

Table 2: Shows the participant's attitudes toward the \#Asingkan Campaign

\begin{tabular}{llcccc}
\hline & & Frequency & Percent & Valid Percent & Cumulative Percent \\
\hline Valid & Disagree & 3 & 3.0 & 20.0 & 20.0 \\
& Neutral & 6 & 6.0 & 40.0 & 60.0 \\
& Agree & 6 & 6.0 & 40.0 & 100.0 \\
& Total & 15 & 15.0 & 100.0 & \\
Missing & System & 85 & 85.0 & & \\
Total & & 100 & 100.0 & & \\
\hline
\end{tabular}

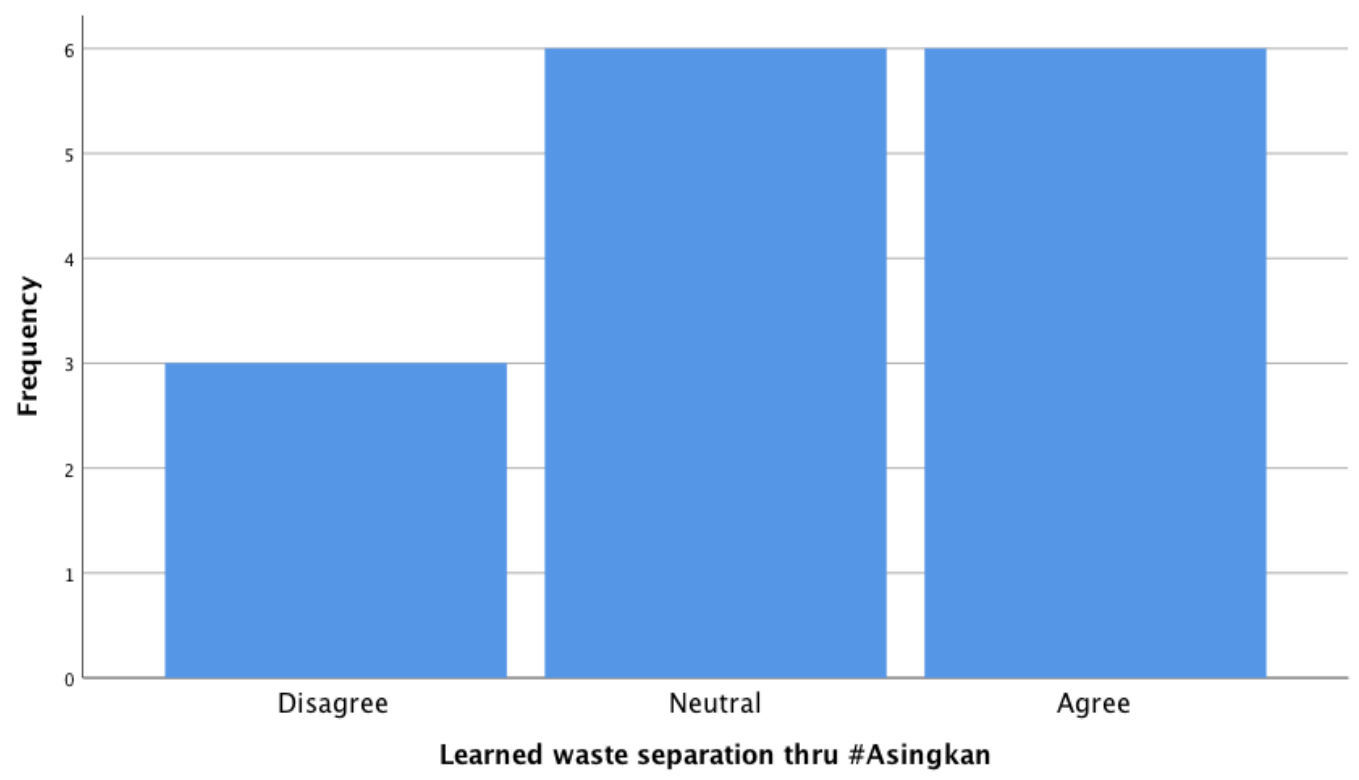

Figure 2: Shows the participant's attitudes toward the \#Asingkan Campaign

The chart shows that $40 \%$ of the respondents agreed that they learned waste segregation through the \#Asingkan Campaign, while $40 \%$ of the respondents are being neutral about it and another $20 \%$ of the respondents are disagreeing with the statement. 
Table 3: Reduce the amount of solid waste being sent to landfills

\begin{tabular}{llcccc}
\hline & & Frequency & Percent & Valid Percent & Cumulative Percent \\
\hline Valid & Disagree & 1 & 1.0 & 6.7 & 6.7 \\
& Neutral & 3 & 3.0 & 20.0 & 26.7 \\
& Agree & 6 & 6.0 & 40.0 & 66.7 \\
& Strongly & 5 & 5.0 & 33.3 & 100.0 \\
& Agree & & & & \\
\multicolumn{7}{l}{ Missing } & Total & 15 & 15.0 & 100.0 & \\
& System & 85 & 85.0 & & \\
\hline
\end{tabular}

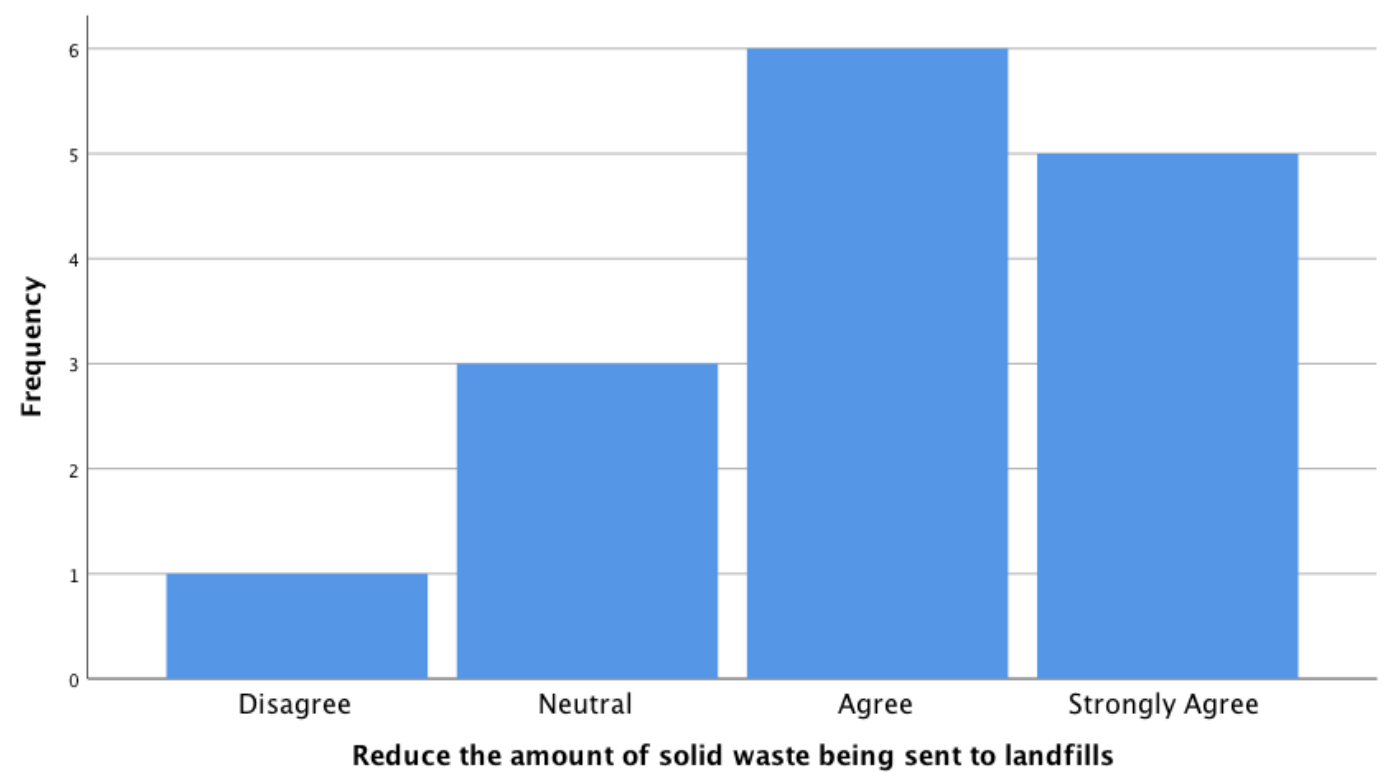

Figure 3: Shows the participant's attitudes toward \#Asingkan Campaign

The result shows $40 \%$ of the respondents agreed with the statement "I believed if I practice waste segregation, I can reduce the amount of solid waste being sent to landfills." $33.3 \%$ of the respondents are strongly agreed, another $20 \%$ of the respondents are being neutral and $6.7 \%$ of respondents are disagreeing with the statement.

Table 4: Shows the frequency of the participant's intention

Do you find \#Asingkan Campaign influential in building your intention?

\begin{tabular}{|c|c|c|c|c|c|}
\hline & & Frequency & Percent & Valid Percent & Cumulative Percent \\
\hline \multirow[t]{3}{*}{ Valid } & Yes & 8 & 8.0 & 53.3 & 53.3 \\
\hline & No & 7 & 7.0 & 46.7 & 100.0 \\
\hline & Total & 15 & 15.0 & 100.0 & \\
\hline Missing & System & 85 & 85.0 & & \\
\hline To & & 100 & 100.0 & & \\
\hline
\end{tabular}




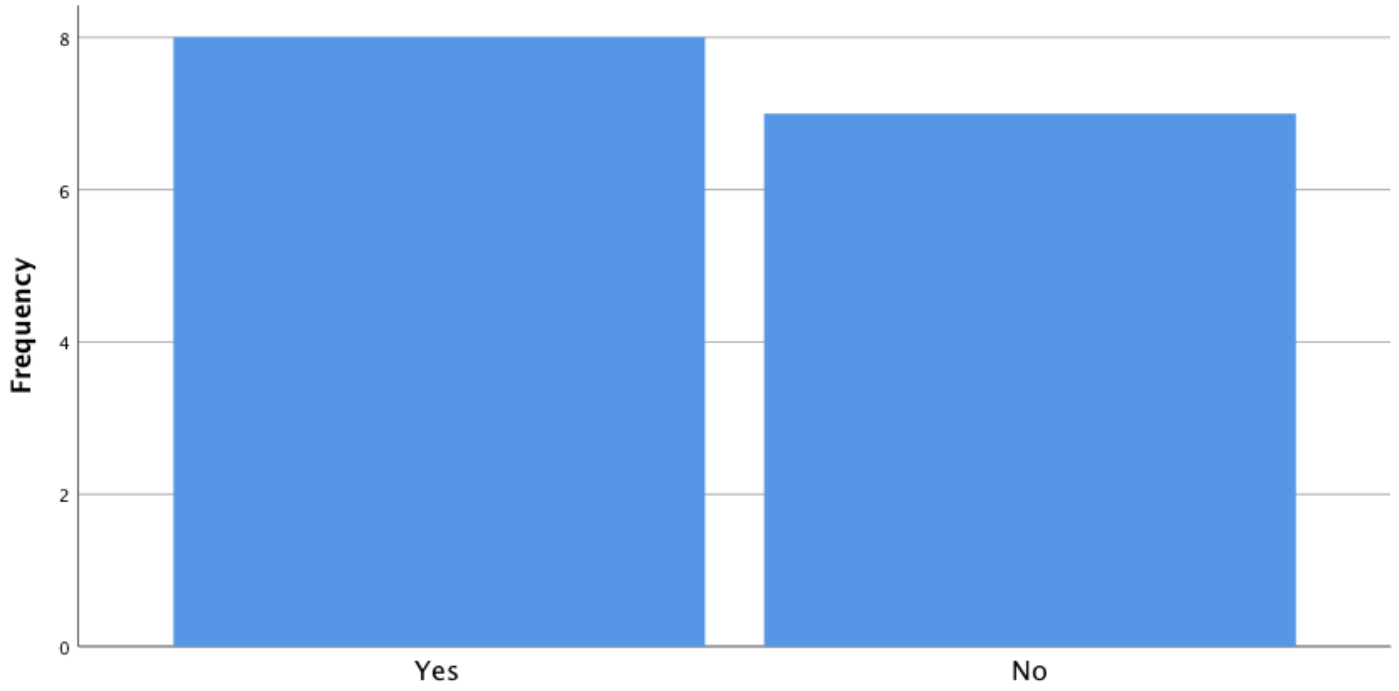

Do you find \#Asingkan infleuntial in building your intention?

Figure 4: Shows the frequency of participant's intention

These two figures conclude that $53.3 \%$ of the respondents found the \#Asingkan Campaign influence them in building their intention to practice the waste segregation. While $46.7 \%$ of the respondents think that the \#Asingkan Campaign did not influence them at all. Another $85 \%$ of the missing system due to the fact that the respondents have never heard of this campaign, therefore they are not qualified to answer the question.

Table 5: Shows the frequency of \#Asingkan Campaign result

\begin{tabular}{llllll}
\hline & \multicolumn{4}{c}{ Do you practice waste separation? } \\
& & Frequency & Percent & Valid Percent & Cumulative Percent \\
\hline Valid & Yes & 5 & 5.0 & 33.3 & 33.3 \\
& No & 10 & 10.0 & 66.7 & 100.0 \\
& Total & 15 & 15.0 & 100.0 & \\
Missing & System & 85 & 85.0 & & \\
Total & & 100 & 100.0 & & \\
\hline
\end{tabular}

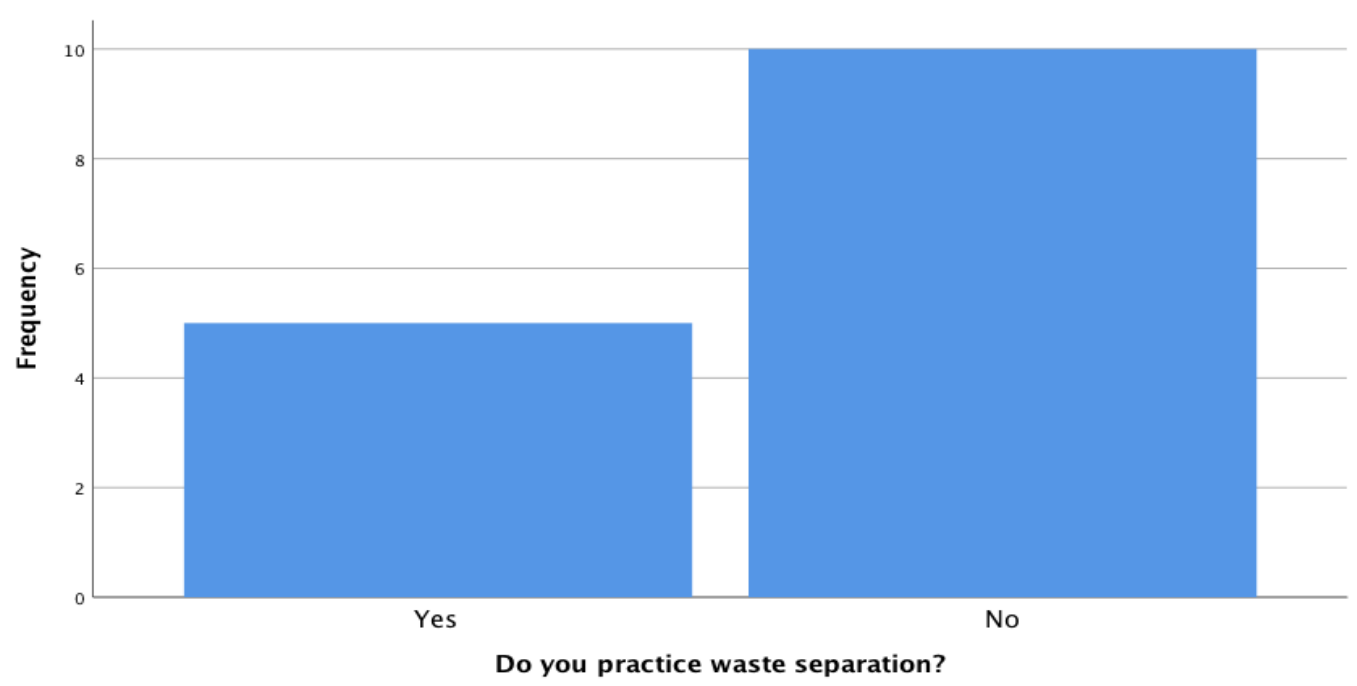

Figure 5: Shows the frequency of \#Asingkan Campaign result

These figures show that out of 15 of the participants, who are aware of the \#Asingkan Campaign, only $33.3 \%$ of the respondents practicing the waste segregation in their daily lives. Another $66.7 \%$ of 
the respondents are not practicing the waste segregation even though they are fully aware of this campaign. 85 of the participants are missing system due to the fact that they never heard of the \#Asingkan Campaign and therefore they are not qualified to answer the question.

Table 6: Shows the frequency of reason for practice

Why do you practice waste separation?

\begin{tabular}{|c|c|c|c|c|c|}
\hline & & Frequency & Percent & Valid Percent & Cumulative Percent \\
\hline \multirow[t]{3}{*}{ Valid } & I love the "mother nature" & 3 & 3.0 & 60.0 & \multirow{5}{*}{$\begin{array}{c}60.0 \\
100.0\end{array}$} \\
\hline & $\begin{array}{l}\text { I adopt my family's culture of } \\
\text { separating waste }\end{array}$ & 2 & 2.0 & 40.0 & \\
\hline & Total & 5 & 5.0 & 100.0 & \\
\hline \multirow{2}{*}{\multicolumn{2}{|c|}{$\begin{array}{l}\text { Missing System } \\
\text { Total }\end{array}$}} & 95 & 95.0 & & \\
\hline & & 100 & 100.0 & & \\
\hline
\end{tabular}

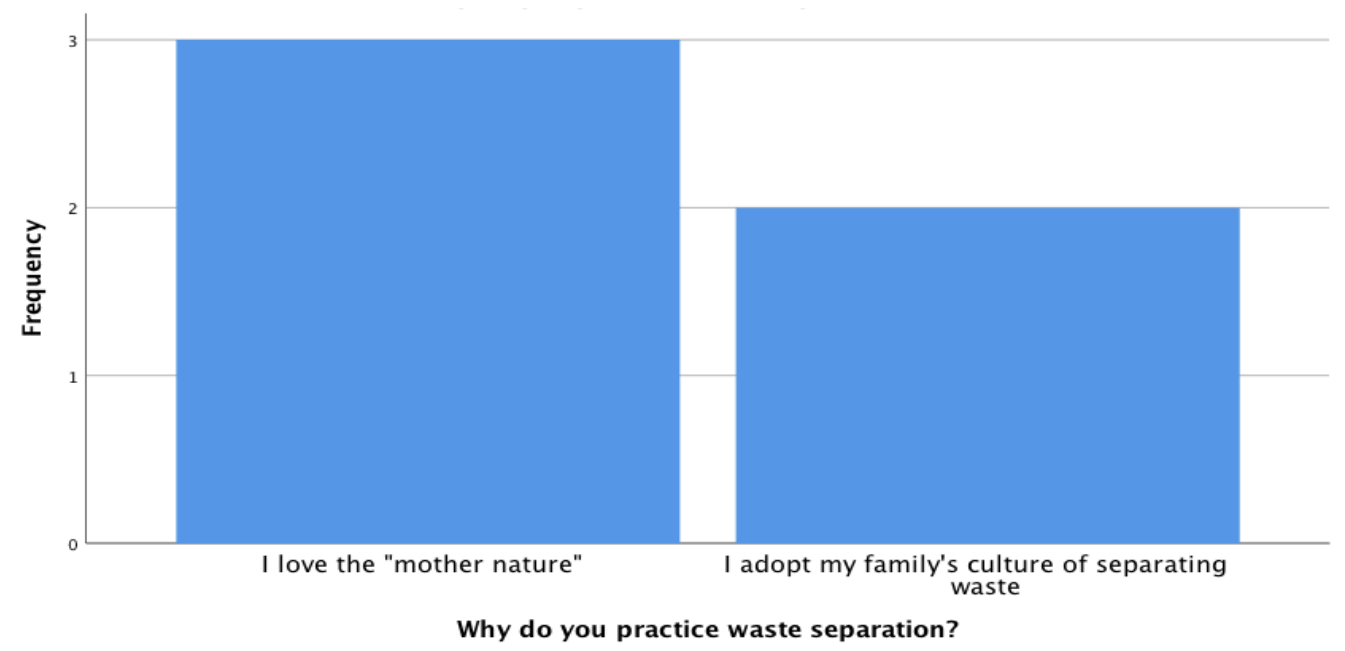

Figure 6: Shows the frequency of reason for practice

These figures show that out of 5 participants who practice the waste segregation, $60 \%$ of the respondents are practicing the waste segregation because of their love to mother nature. While $40 \%$ of the respondents did it because they adopting their family culture of separating waste. Another 95 of the missing system due to the fact that there are only 5 participants who are practicing it before, therefore others are not qualified to answer this question.

Table 7: Shows the frequency of reason not to practice

\begin{tabular}{|c|c|c|c|c|c|}
\hline \multicolumn{6}{|c|}{ Why don't you practice waste separation? } \\
\hline & & Frequency & Percent & Valid Percent & Cumulative Percent \\
\hline \multirow[t]{4}{*}{ Valid } & $\begin{array}{l}\text { I feel that waste separation are } \\
\text { complicated and fussy }\end{array}$ & 3 & 3.0 & 30.0 & 30.0 \\
\hline & $\begin{array}{l}\text { I don't have extra time for waste } \\
\text { separation }\end{array}$ & 3 & 3.0 & 30.0 & 60.0 \\
\hline & $\begin{array}{l}\text { I feel that \#Asingkan campaign is } \\
\text { not convincing }\end{array}$ & 4 & 4.0 & 40.0 & 100.0 \\
\hline & Total & 10 & 10.0 & 100.0 & \\
\hline Missing & System & 90 & 90.0 & & \\
\hline Total & & 100 & 100.0 & & \\
\hline
\end{tabular}




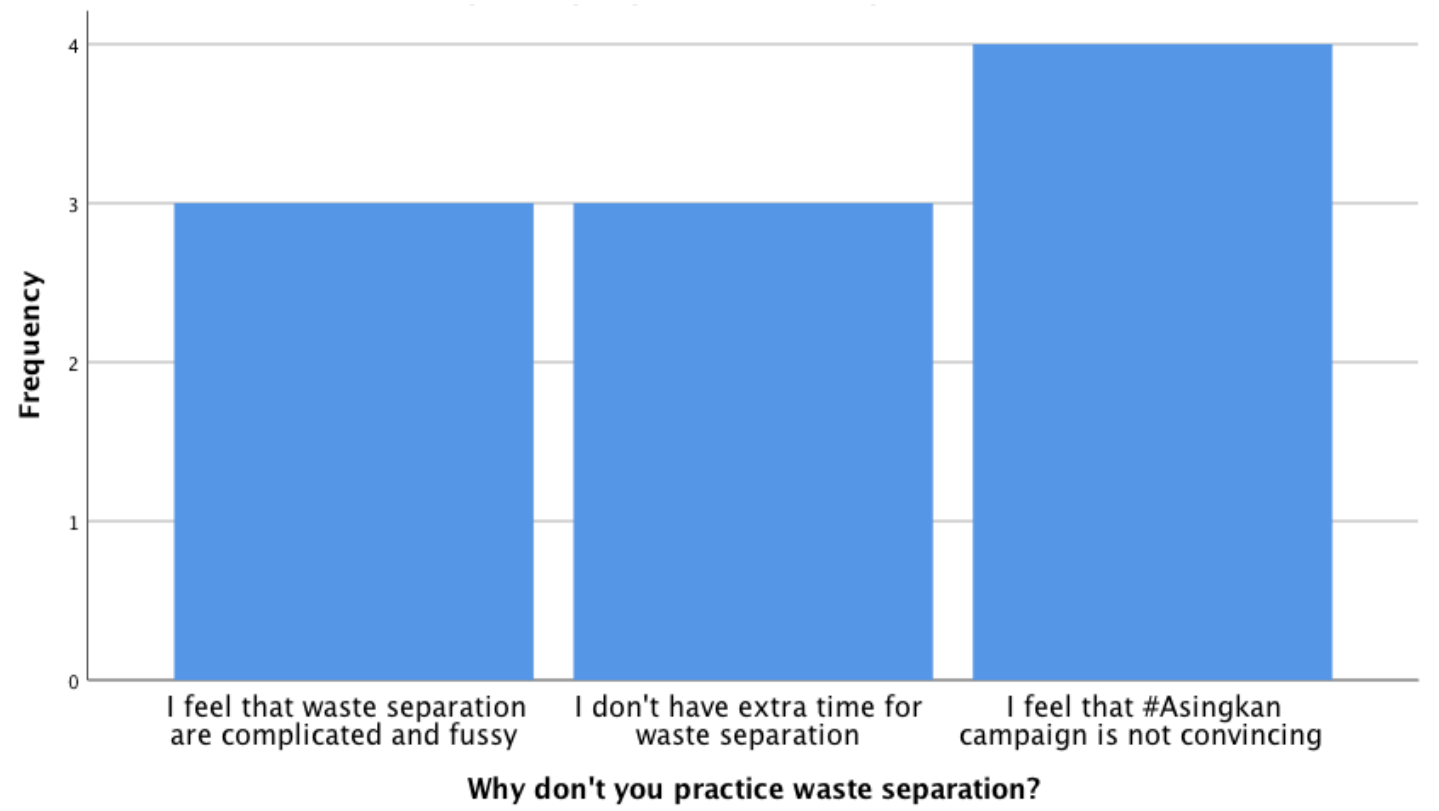

Figure 7: Shows the frequency of reason not to practice

These figures show that out of 10 participants who are aware of this \#Asingkan Campaign but failed to practice the waste segregation. $40 \%$ of the respondents felt that the \#Asingkan Campaign are not convincing them at all. Another $30 \%$ of the respondents felt that waste separation is complicated and they don't have extra time for waste separation. 90 of missing systems are due to the fact that they aware are practicing the waste segregation and therefore they are not qualified to answer this question.

Table 8: Shows the frequency of the effectiveness of the \#Asingkan Campaign

\begin{tabular}{llcccc}
\hline \multicolumn{5}{c}{ Do you think the \#Asingkan Campaign is effective? } \\
& & Frequency & Percent & Valid Percent & Cumulative Percent \\
\hline Valid & Yes & 6 & 6.0 & 6.0 & 6.0 \\
& No & 94 & 94.0 & 94.0 & 100.0 \\
& Total & 100 & 100.0 & 100.0 & \\
\hline
\end{tabular}

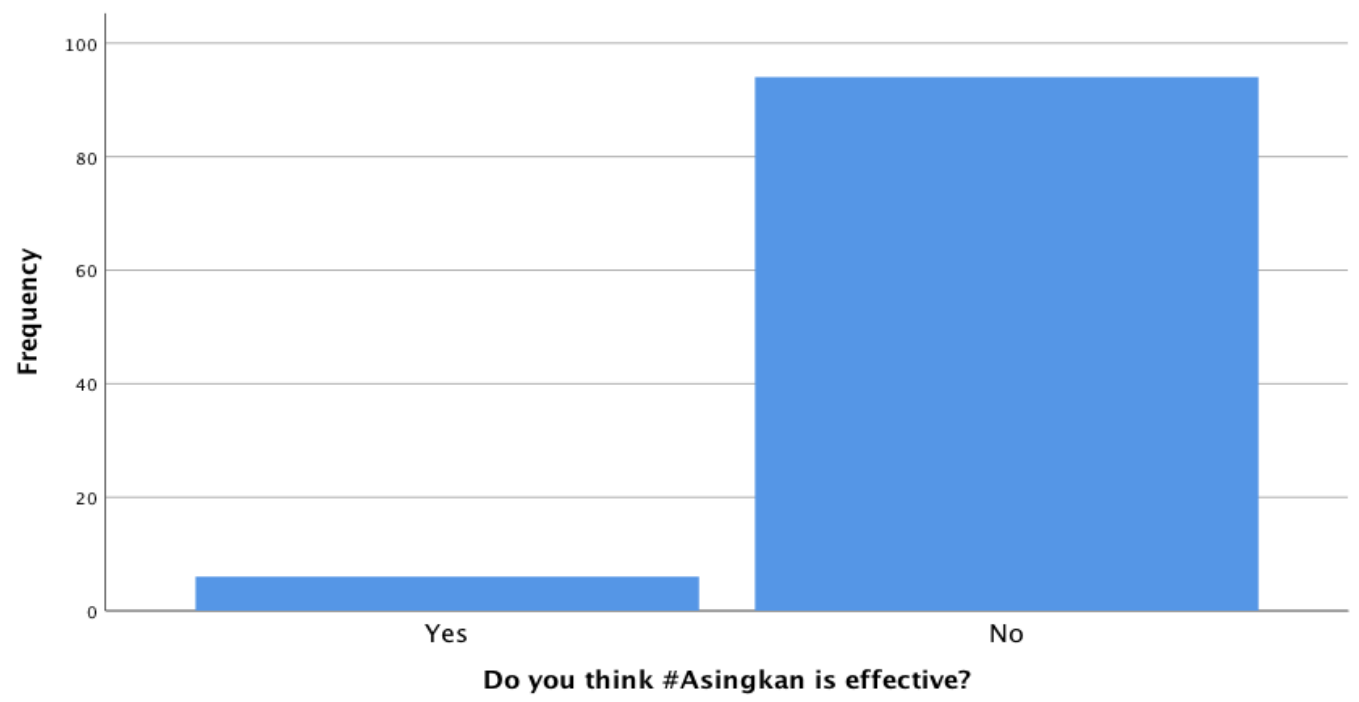

Figure 8: Shows the frequency of the effectiveness of the \#Asingkan Campaign

This result shows that only $6 \%$ of the respondents think that the \#Asingkan Campaign is effective and the majority $94 \%$ of the respondents declined. 


\section{CONCLUSION}

Based from the findings and respondents' reception, the researcher has come out with a conclusion that the waste segregation the \#Asingkan Campaign, which has been introduced by the Malaysian government, is not running effectively in this country and still far away from its main objective which is to increase the nation's recycling rate as well as to save the environment. It is so pathetic that the exposure and participant level of the campaign are so low while the government spend massive amount of times, efforts and budget into this campaign.

Public awareness of solid waste segregation has yet to reach a satisfactory level, although the government has made this compulsory since September 2015. Malaysian awareness on waste segregation is still at a low level and very much behind compared with a number of developed countries. The majority of Malaysian still found this waste segregation campaign a 'foreign' idea. A big reason for the waste problem in Malaysia is because it lacks of public awareness and environmental education.

Therefore, a proper solid waste management must be implemented in order to reduce the amount of solid waste in landfills. More ground works are required to increase the effectiveness in achieving the targeted objectives. Continuous campaign on environmental awareness and education should not be neglected and solid waste segregation programmes must be strategically planned. The government needs to keep this segregation-of-waste programme going if they are really serious about reducing waste in landfills. The Malaysia government and local authorities have to work together to ensure this waste segregation programme effective.

\section{RECOMMENDATION}

Through the feedbacks from the survey questionnaire, the researcher would like to suggest few suggestions or initiatives that can help the \#Asingkan Campaign in Malaysia to achieve its objective.

\subsection{A New Policy and enforcement for Waste Management in Malaysia}

The Malaysia government should be enforcing the law to make sure every household separates their waste accordingly. The government should impose a waste tax in order to make this programme effective. Where either resident gets charged each time they have a residual waste to be picked up, or they get charged by the weight of their waste. This is to assure the country's long-term strategy for environmental protection.

\subsection{Educate and nurture the young generation}

The only way to make a difference is to educate people, especially to nurture the young generation, on the negatives of solid waste into landfills and to make them understand that what they pollute will end up harming them one day. The students in school should be more exposed with the 3Rs: Reduce, Reuse and Recycle concept. They should learn about waste management and how to treat different types of rubbish.

\section{REFERENCE}

Badgie, D., Samah, A. A., Manafl, L., \& Muda, A. B. (2012). Assessment of Municipal Solid Waste Composition in Malaysia: Management, Practice, and Challenges. Polish journal of Environmental Studies, 21(3), 539-547. Retrieved 16 November 2016, from http://www.nswaienvis.nic.in/Waste_Portal/Research_papers/pdf /Assessment of MWS Composition.pdf 
Cilisos.my (2017). Jo-Lyn: It's been a year since Malaysia started waste separation. Here's how much we've progressed. Retrieved 30 May 2017 from https://cilisos.my/its-been-a-year-since-malaysiastarted-waste-separation-how-are-we-doing-so-far/

CleanMalaysia. (2015). Waste Management in Malaysia: In the Dumps. Retrieved 16 Novermber 2016, from http://cleanmalaysia.com/2015/09/04/waste-management-in- malaysia-in-the-dumps/

Fatma Sabariah Alias, Latifah Abd Manaf, Mariani Ariffin, Sabrina Ho Abdullah (2018). Solid Waste Minimization in Malaysia. Pertanika Journal of Scholarly Research Reviews. PJSRR (2018) 4(3): 26-41. eISSN: 2462-2028

Freemalaysiatoday.com (2018). Rosli Khan: Why are we so far behind in waste management? Retrieved 20 December 2018 from https://www.freemalaysiatoday.com/category/opinion/2018/12/20/whyare-we-so-far-behind-in-waste-management/

Freemalaysiatoday.com (2019). Soo Wern Jun: Garbage separation drive turning out to be a wasted effort? Retrieved 6 January 2019 from

Greenchoices. (2016). Environmental Impacts. Retieved 16 November 2016, from

Hoornweg, Daniel; Bhada-Tata, Perinaz. 2012. What a Waste: A Global Review of Solid Waste Management. Urban development series;knowledge papers no. 15. World Bank, Washington, DC. C) World Bank. https://openknowledge.worldbank.org/handle/10986/17388

Housseinpour, M., Mohamed, Z., Rezai, G., Shamsudin, M. N., \& Ismail, A. L. (2015). How Go Green Campaign Effects on Malaysia Intention Towards Green Behaviour. Journal of Applied Sciences, 15, 939-933. Doi: 10.3923/jas.2015.929.933

https://pdfs.semanticscholar.org/8817/795ec8dad13746a02371caf5ce56220e0bb4.pdf?.ga=2.1333148 94.1335078058.1567697285-70757390.1567697285

https://www.freemalaysiatoday.com/category/nation/2019/01/06/garbage-separation-drive-turningout-to-be-a-wasted-effort/

https://www.greenchoices.org/green-living/waste-recycling/environmental-impacts

Iwan Budhiarta, Chamhuri Siwar, Hassan Basri (2011). Current Status of Municipal Solid Waste Generation in Malaysia. International Journal on Advanced Science Engineering Information Technology. Vol. 2 (2012) No. 2 (ISSN: 2088-5334) pp16-21.

Kumari, S. (2016). Public Taking Solid Waste Separation Ruling Lightly. Promotional Portal of Ministry of Dosmestic Trade, Co-operatives and Consumerism. Retrieved 20 November 2016, from http://kpdnkk.bernama.com/featuresEn.php?id $=1154590$

Malay Mail (2015). Melissa Chi: Waste segregation: Start small, environmentalists urge the $\begin{array}{llllll}\text { government. } & \text { Retrieved } & 26 & \text { August } & 2015 & \text { from }\end{array}$ https://www.malaymail.com/news/malaysia/2015/08/26/waste-segregation-start-smallenvironmentalists-urge-the-government/958369

Malay Mail (2016). Jonathan Edward: Waste segregation enforcement starts today. Retrieved 1 June 2016 from https://www.malaymail.com/news/malaysia/2016/06/01/waste-segregation-enforcementstarts-today/1131527

Malay Mail (2016). Separate solid wastes: Compound enforcement begins in June. Retrieved 16 May 2016 from https://www.malaymail.com/news/malaysia/2016/05/16/separate-solid-wastescompound-enforcement-begins-in-june/1121135

Malay Mail (2019). Ida Nadirah Ibrahim: Minister: We need two years before waste segregation can be implemented nationwide. Retrieved 15 January 2019 from https://www.malaymail.com/news/malaysia/2019/01/15/minister-we-need-two-years-before-wastesegregation-can-be-implemented-nati/1712920

Malay Mail (2019). Public awareness of solid waste segregation still not satisfactory, says deputy $\begin{array}{lllll}\text { minister. } & \text { Retrieved } & 24 & \text { July } & 2019\end{array}$ https://www.malaymail.com/news/malaysia/2019/07/24/public-awareness-of-solid-wastesegregation-still-not-satisfactory-says-dep/1774411

Malaysiakini (2018). Nur Imani binti Abdullah: Time M'sians separated their solid waste at home. Retrieved 1 October 2018 from https://www.malaysiakini.com/letters/445518

Poskod.my. 6 Things to Know About Separating Your Trash. https://poskod.my/cheat-sheets/needknow-mandatory-waste-separation-scheme/

Rezai, G., Hosseinpour, M., Shamsudin, M. N., Ismail, A. L., \& Sharifuddin, J. (2015). Effects of GoGreen Campaigns on Changing Attitudes Towards Green Behaviour. Pertanik Journals of Social 
Sciences and Humanities, 23(S), 77-92. Retrieved 20 November 2016, from http://www.pertanika.upm.edu.my/Pertanika\%20PAPERS/ JSSH\%20Vol.\%2023\%20(S)\%20Jun.\%202015/07\%20JSSH\%201356-2015.pdf

Tey, Jia Sin and Goh, Kai Chen and Kek, Sie Long and Goh (2013). Current practice of waste management system in Malaysia: Towards sustainable waste management.

The Star Online (2017). Low awareness on recycling among Malaysians. Retrieved 20 August 2017 from https://www.thestar.com.my/news/nation/2017/08/20/low-awareness-on-recycling-amongmalaysians/

The Star Online (2018). Rulim: Green ways to manage waste. Retrieved 9 September 2018 from https://www.thestar.com.my/news/nation/2018/09/09/green-ways-to-manage-waste-swcorp-goesfor-green-technology-and-educating-the-young

Time Out (2016). Syarifah Syazana: How to separate your household waste: A guide If you're confused about how and what you need to separate, here's a handy guide. Retrieved 1 June 2016 from https://www.timeout.com/kuala-lumpur/things-to-do/how-to-separate-your-household-waste-aguide

ZA Zainu, A. Songip. (2017). Policies, Challenges and Strategies for Municipapl Waste Management in Malaysia. Journal of Science, Technology and Innovation Policy; Vol 3, No 1 (2017): June 2017. (eISSN): 2550-2018 http://jostip.org/index.php/jostip/article/view/47 
Idealogy Journal

Volume 5 Issue 22020
溇: IDEALOGY

JOURNAL 